\title{
Cordonnier Grade 2 Viral Complication, Varicella Zoster Virus Infection
}

National Cancer Institute

\section{Source}

National Cancer Institute. Cordonnier Grade 2 Viral Complication, Varicella Zoster Virus

Infection. NCI Thesaurus. Code C138305.

Any Varicella zoster virus infection. 